\title{
IN VIVO NEUTRON ACTIVATION ANALYSIS FOR BONE CALCIUM (INVAA) IN MALIGNANT HYPERTHERMIA SUSCEPTIBLE PATIENTS
}

\author{
B.A. BrITT, J.E. HARRISON, AND K.G. MCNEILL
}

\section{INTRODUCTION}

WE HAVE OBSERVED that some non rigid Malignant Hyperthermic Susceptible (MHS) patients have a greater than normal incidence of fractures. Radiologically their long bones are slightly thinner than normal. Excessive numbers of caries because of thin dental enamel may also be present.'

The Malignant Hyperthermic ( $\mathrm{MH}$ ) defect thus appears to involve cells of bone appendages as well as of muscle. We have, therefore, measured the concentration of calcium in bone. We have found it to be reduced. This is additional evidence in favour of the hypothesis that $\mathrm{MH}$ is a widespread defect affecting tissues and organs throughout the body:

\section{METHODS}

\section{Selection of patients}

Patients who had given their informed consent were divided into four groups on the basis of their anaesthetic histories and skeletal muscle caffeine contracture tests, as follows:

(1) Non-rigid MHS patients - Patients who had had an episode of $\mathrm{MH}$ not associated with skeletal muscle rigidity and whose skeletal mụscle fascicles developed a smaller than normal contracture in the presence of caffeine.

(2) Rigid MHS patients - Patients who had had an episode of malignant hyperthermia associated with skeletal muscle rigidity and whose skeletal muscle fascicles developed greater than normal contractures in the presence of caffeine plus halothane.

B.A. Britt, M.D., M.Se., F.R.C.P.(C), Associate Professor, Departments of Anaesthesia and Pharmacology, University of Toronto Senior Staff Anaesthetist, Toronto General Hospital, Toronto, Ontario, Canada.

J.E. Harrison, M.D., Associate Professor, Department of Medicine, University of Toronto; Consultant, Department of Medicine. Toronto General Hospital, Toronto, Ontario, Canada.

K.G. MCNeill, M.A., D.Phil., Professor, Depar1ments of Medicine and Physics, University of Toronto, Toronto, Ontario, Canada. 117
(3) Rigid MHS relatives - Relatives of rigid MHS patients whose skeletal muscle fascicles developed greater than normal contractures in the presence of caffeine plus halothane.

(4) Normal Relatives - Relatives of rigid or non-rigid MHS patients who had had no adverse reactions during anaesthesia and whose skeletal fascicles developed normal contractures in the presence of caffeine and caffeine plus halothane.

\section{Method of Measuring Total Torso Calcium by} Neusron Activation Analysis ${ }^{2-6}$

Permission for this study was received from the Human Experimentation Committee of the University of Toronto. All patients in the study gave their written informed consent.

${ }^{48} \mathrm{Ca}$ in the body is converted by neutron capture to ${ }^{49} \mathrm{Ca}$. This latter isotope is radioactive and decays with a half-life of 8.8 minutes, emitting a 3. 1-MeV gamma ray that may be detected by $\mathrm{NaI}$ crystals in a whole body counter.?

The subjects were irradiated for 20 minutes in a shielded neutron chamber, the walls of which were 18-inch concrete. The neutrons were produced by 12 plutonium-beryllium sources (Monsanto Chemical Company), each of 5 curies and with neutron output of approximately $1.2 \times 10^{7}$ neutrons/sec. The sources were placed symmetrically above and below the trunk; the source-toskin distance was fixed for any one individual and was about $12 \mathrm{~cm}$ in all cases. The subject lay on a wooden board placed over a stretcher on which he or she was positioned with respect to the stretcher and the sources using the sternal notch as a reference point: The wooden board had a thickness of $4 \mathrm{~cm}$ and acted as a premoderator for the fast neutrons from below. There was a similar wood premoderator above the subject but with an air space of $8 \mathrm{~cm}$ between the skin and the bottom of the premoderator. Above the upper sources (and correspondingly below the lower ones) were thick $(30 \mathrm{~cm})$ hydrogenous reflectors that increased the neutron flux in the irradiation volume and also provided additional shielding. Thermal flux measurements showed that the area irradiated (to a line where the thermal fux at the surface drops off to 50 per cent of its maximum) 
was $60 \mathrm{~cm} \times 30 \mathrm{~cm}$. This area was constant for all subjects.

The counting geometry to the 50 per cent counting efficiency lines was such that a similar area of the subject was measured by the four fixed Nal crystals of the whole-body counter. Once again, the sternal notch was used for positioning. Thus, a constant area was irradiated and counted. For different subjects this area accommodated different proportions of the total bone in the body. With a six-foot person, approximately one third of the total bone was viewed whereas with a four-foot individual the figure was about 60 per cent. These estimates were based on measurements of the bones of human skeletons.

The counting procedure consisted of a 20minute count starting 3 minutes after the end of the irradiation. The calcium count was obtained by measuring the area under the ${ }^{49} \mathrm{Ca}$ photopeak at $3.1 \mathrm{MeV}$ and subtracting from this a standard background and an amount determined by the magnitudes of the ${ }^{24} \mathrm{Na}$ and ${ }^{38} \mathrm{Cl}$ peaks at 2.75 and $2.2 \mathrm{MeV}$, respectively. These corrections were determined from phantom studies. They were made necessary by incomplete resolution of the photopenks of ${ }^{24} \mathrm{Na}$ and ${ }^{49} \mathrm{Ca}$ at 2.75 and $3.1 \mathrm{MeV}$, respectively, and the accidental summing of the gamma rays from sodium and chlorine. Typically, the gross count was about 1,800 in the ${ }^{49} \mathrm{Ca}$ peak region, and from this was subtracted 590 counts for background, 80 counts due to the sodium contribution, and 40 counts due to the chlorine contribution. A correction was then made for counting efficiency based on the thickness of the individual.

As persons of larger size would be expected to have more calcium than smaller persons, the net calcium count by itself is not diagnostic. On the basis of measurements on normal adult subjects (20-55 years old), we find that the calcium count varies closely with the cube of the subject's height. The ratio of a patient's count to the count of a normal subject of the same height (predicted on the cubic equation) is then defined as the Calcium Bone Index (CaBl) of the patient. Clearly for normals the CaBI averages 1.0. For normals the spread about unity is \pm 0.12 ( 1 s.d.). For comparison, osteoporotic subjects have a mean $\mathrm{CaBI}$ of 0.69; on the other hand, values greatly in excess of unity are found in osteosclerosis and osteopetrosis.

The stability of the counting apparatus with respect to both overall efficiency and resolution is checked by counting a thorium standard before and after the main counting procedure. A con- tinuing check of reproducibility of the method is made by measuring the calcium in a skeletal phantom and the chlotine in a $\mathrm{KCl}$ phantom.

The dose equivalent received by a patient during the irradiation procedures was about $0.4 \mathrm{rem}$ (quality factor of 10 for fast neutrons was used). The dose was almost entirely ( 90 per cent) due to the neutrons, with smaller contributions coming from gamma rays from the $\mathrm{Pu}$-Be sources (from $\left.{ }^{12} \mathrm{C}\right)$ and from induced radioactivity.

\section{Method of Measuring Sketetal Muscte Caffeime} Contracsure

The increase in the resting tension of the skeletal muscle fascicles induced by caffeine alone and by caffeine plus $I .0$ volume per cent halothane at $22^{\circ}$ was carried out by the methods previously described by us. ${ }^{8-10}$

Thus skeletal muscle samples were obtained from the quadriceps muscle. Prior to dissection each end of the fascicle was secured with a black silk suture and then meticulously dissected free from the surrounding muscle while maintaining constant tension on the sutures in such a manner as to preserve the whole cells free from contractures or excessive stretching. Care was taken that direction of the long cut ran parallel to the long side of the muscle cells. The muscle samples were then immediately transported to the laboratory in Ringer's solution maintained at $22^{\circ} \mathrm{C}$. The time elapsed between excision and further processing in the laboratory was about ten minutes. The specimens were trimmed free of any irregularities or remaining fat. To permit replicate measurements each was divided into several strips approximately $1-3 \mathrm{~mm} \times 10-20 \mathrm{~mm}$, weighing roughly $0.1-0.3$ grams.

Each muscle strip. secured by a silk suture to an electrode housing, was immersed in $40 \mathrm{ml}$ of a Krebs Ringer's solution gassed with 95 per cent oxygen and 5 per cent carbon dioxide (carbogen) at $\mathrm{cH}^{+} 40 \mathrm{nmol} \cdot 1$ (pH 7.4) adapted for human tissues. The upper end of the muscle was connected by a second silk suture to a force displacement transducer. Isometric tension was recorded with a polygraph. The initial tension was set at 0.5 to 2.0 grams. The magnitude of the contracture is not altered significantly by changing the baseline tension from 0.5 to 2.0 gram. In order to assess viability the muscle was stimulated every five seconds through platinum electrodes connected to a square wave stimulator which was set to deliver 8 volt impulses of 20 milliseconds duration. Carbogen was bubbled through the bath at $15-20 \mathrm{ml}$ per minute. Caffeine in increments 
TABLE I

Arithmetic Means for all Ages of Patients

\begin{tabular}{|c|c|c|c|c|c|c|}
\hline $\begin{array}{l}\text { Patient } \\
\text { classification }\end{array}$ & & $\begin{array}{l}\text { Age } \\
\text { (yrs) }\end{array}$ & Caffeine & $\begin{array}{c}\text { Caffeine } \\
+ \\
\text { halothane }^{\circ}\end{array}$ & $\begin{array}{l}\text { Bone } \\
\text { calcium } \\
\text { index }\end{array}$ & $\begin{array}{c}\text { Present } \\
\text { maximum } \\
\text { height (cm) }\end{array}$ \\
\hline $\begin{array}{l}\text { Rigid MHS } \\
\text { patients }\end{array}$ & $\begin{array}{r}\bar{X} \\
\text { S.E. } \\
\mathbf{N}\end{array}$ & $\begin{array}{r}27.9 \\
5.2 \\
17\end{array}$ & $\begin{array}{r}9.32 \\
1.06 \\
17\end{array}$ & $17^{.932}$ & $17^{.038}$ & $\begin{array}{c}154.7 \\
6.1 \\
16\end{array}$ \\
\hline $\begin{array}{l}\text { Rigid MHS } \\
\text { relatives }\end{array}$ & $\begin{array}{r}\bar{X} \\
\text { S.E. } \\
\text { N }\end{array}$ & $\begin{array}{r}32.3 \\
2.1 \\
55\end{array}$ & $\begin{array}{l}8.95 \\
0.63 \\
55\end{array}$ &.$_{55}^{.920} .105$ & $\begin{array}{r}.919 \\
.017\end{array}$ & $\begin{array}{r}164.3 \\
1.8 \\
54\end{array}$ \\
\hline $\begin{array}{l}\text { Notmal } \\
\text { relatives }\end{array}$ & $\begin{array}{r}\bar{X} \\
\text { S.E. } \\
N\end{array}$ & $\begin{array}{l}22.8 \\
2.5 \\
33\end{array}$ & $\begin{array}{r}17.09 \\
1.29 \\
33\end{array}$ & $\begin{array}{r}1.951 \\
33^{.086}\end{array}$ & $33^{.023}$ & $\begin{array}{r}156.5 \\
3.2\end{array}$ \\
\hline $\begin{array}{l}\text { Non-rigid } \\
\text { MHS patients }\end{array}$ & $\begin{array}{r}\bar{X} \\
\text { S.E. } \\
N\end{array}$ & $\begin{array}{c}22.0 \\
6.5 \\
7\end{array}$ & $\begin{array}{c}26.21 \\
2.75 \\
7\end{array}$ & $\begin{array}{r}2.479 \\
.350 \\
7\end{array}$ & $7^{.0340}$ & $\begin{array}{c}143.3 \\
8.6 \\
5\end{array}$ \\
\hline
\end{tabular}

"Caffeine specific concentration i.e., mmol of caffeine required to raise the resting tension of a skeletal muscle fascicle by 1.0 gram in absence of halothane.

${ }^{\circ}$ Caffeine specific concentration in presence of 1.0 volume per cent halothane.

from 1.0 to $32.0 \mathrm{mmol}$ was added directly to the bath. Each caffeine dose was left in the bath until the contracture plateau had been reached. The caffeine was then removed and replaced by an amount double that of the previous dose. The parameter measured was the plateau contracture expressed as grams of tension increase produced by each addition of each dose of caffeine. Once a contracture greater than one gram was reached the caffeine was removed by repeated washing. The muscle was then equilibrated for 15 minutes with 1.0 volume per cent halothane added through the carbogen line. Caffeine was then again added, this time in increments ascending from $0.25 \mathrm{mmol}$. The gram tension increase for each dose was then measured as before.

From the $\log$ caffeine and $\log$ caffeine plus halothane response curves, the concentration of caffeine in mmol required to raise the resting tension of the isometric skeletal muscle preparation by one gram was calculated. This value was defined as the "caffeine specific concentration" (Tables I, III, V and VII).

\section{Results}

The results show that in comparison with the normal relatives the CaBI was reduced in the rigid MHS patients, the rigid MHS relatives and in the non-rigid MHS patients (Tables I and II). The reductions were most marked for the nonrigid MHS patients but were statistically significant for all groups.
These differences were at least partially due to age differences among the different groups. Consideration of only those patients between the ages of 16 and 60 years reveals that, while the bone calcium index still remained substantially lower in the non-rigid MHS patients than in the normal relatives, the differences between the normal relatives and the rigid relatives or patients were reduced although not entirely eliminated (Tables III and IV).

Sex was also an influencing factor. Thus the differences betweent the normal relatives and the non-rigid probands and between the normal relatives or the rigid relatives and rigid probands were greater for males than for females (Tables V-VIII).

The slighily lower heights and shorter arm spans observed in the non-rigid males was mainly a reflection of their younger age. Otherwise no differences were observed in age, arm span or height among the four groups (Tables l-VIII).

\section{Discussion}

The reason for the moderately low bone calcium indices in the rigid MHS patients and the substantially low bone indices in the non-rigid MHS patients is not entirely clear to us.

Whether the decrease in the calcium of the bones of MHS patients is due to a primary $\mathrm{MH}$ defect of the bone cells similar to that of the muscle cells or whether the decrease is secondary to some other factor is not certain. 
TABLE IT

t-Test-ALL AGes

\begin{tabular}{|c|c|c|c|c|c|}
\hline t-Test ratios & Age & Caffeine & $\begin{array}{c}\text { Caffeine } \\
+ \\
\text { halothane }\end{array}$ & $\begin{array}{l}\text { Bone } \\
\text { calcium }\end{array}$ & $\begin{array}{c}\text { Present } \\
\text { measured } \\
\text { height }\end{array}$ \\
\hline $\begin{array}{l}\text { Rigid patient/rigid } \\
\text { relative, } t^{*}\end{array}$ & 0.96 & 0.23 & 0.06 & 1.16 & 2.00 \\
\hline $\begin{array}{l}\text { Rigid patient/normal } \\
\text { relative, } t\end{array}$ & 1.04 & $4.53 \dagger$ & $4.98 \dagger$ & $2.82^{*}$ & 0.35 \\
\hline $\begin{array}{l}\text { Rigid patient/non-rigid } \\
\text { patient, } t\end{array}$ & 0.80 & $6.55 \dagger$ & $5.03 \uparrow$ & $2.34^{*}$ & 1.32 \\
\hline $\begin{array}{l}\text { Rigid patient/normal } \\
\text { relative, } t\end{array}$ & $2.62^{*}$ & $6.43 \dagger$ & $6.84 \dagger$ & $2.36^{*}$ & $2.05^{*}$ \\
\hline $\begin{array}{l}\text { Rigid relative/non-rigid } \\
\text { patient, t }\end{array}$ & 1.56 & 2.491 & $5.67 \dagger$ & 3.421 & $2.70^{*}$ \\
\hline $\begin{array}{l}\text { Normal relative/non-rigid } \\
\text { patient, t }\end{array}$ & 0.12 & $3.81 \dagger$ & 1.85 & $4.55 t$ & 1.62 \\
\hline \multicolumn{6}{|c|}{$\begin{array}{l}\text { P }<0.05 \\
+\mathrm{P}<0.01 \\
\text { aThe t-values were abtained from comparisons based on analyses of variance. Their significance levels were } \\
\text { assessed on the basis of the Tukey-Newman-Keuls }(A, B) \text { sequential multiple comparison procedure. } \\
\text { (A) Newman, D. The distribution of the range in samples from a normal population expressed in terms of an } \\
\text { independent estimate of the standard deviation. Biometrika, } 31,20-30 \text { (1939). } \\
\text { (B) Keuls, M. The use of the studentized range in connection with the analysis of variance. Euphytica, 1, } \\
112-122 \text { (1952). }\end{array}$} \\
\hline
\end{tabular}

TABLE III

Arithmetic Means for Patients Between 16 and 60 Years of Age

\begin{tabular}{|c|c|c|c|c|c|c|}
\hline $\begin{array}{l}\text { Patient } \\
\text { classification }\end{array}$ & & $\begin{array}{c}\text { Age } \\
\text { (yrs) }\end{array}$ & Caffeine $^{a}$ & $\begin{array}{c}\text { Caffeine } \\
+ \\
\text { halothane }^{*}\end{array}$ & $\begin{array}{l}\text { Bone } \\
\text { calcium } \\
\text { index }\end{array}$ & $\begin{array}{c}\text { Present } \\
\text { maximum } \\
\text { height }(\mathrm{cm})\end{array}$ \\
\hline $\begin{array}{l}\text { Rigid MHS } \\
\text { patients }\end{array}$ & $\begin{array}{l}\bar{X} \\
\text { S.E. } \\
N\end{array}$ & $\begin{array}{l}32.9 \\
5.4 \\
8\end{array}$ & $8^{7.80}$ & $8^{.218}$ & $8^{.038}$ & $\begin{array}{c}167.0 \\
3.4 \\
8\end{array}$ \\
\hline $\begin{array}{l}\text { Rigid MHS } \\
\text { relatives }\end{array}$ & $\begin{array}{r}\overline{\mathbf{X}} \\
\text { S.E. } \\
\text { N }\end{array}$ & $\begin{array}{r}35.4 \\
1.9 \\
43\end{array}$ & $\begin{array}{l}9.06 \\
0.74 \\
43\end{array}$ & $43^{. .950}$ & $43^{.020}$ & ${ }_{42}^{168.1}$ \\
\hline $\begin{array}{l}\text { Normal } \\
\text { relatives }\end{array}$ & $\begin{array}{r}\bar{X} \\
\text { S.E. } \\
N\end{array}$ & $\begin{array}{l}31.5 \\
2.6 \\
20\end{array}$ & $\begin{array}{l}15.33 \\
1.48 \\
20\end{array}$ & $\begin{array}{r}1.858 \\
20.092\end{array}$ & $20^{1.0013}$ & $\begin{array}{c}166.9 \\
1.7 \\
19\end{array}$ \\
\hline $\begin{array}{l}\text { Non-rigid } \\
\text { MHS patients }\end{array}$ & $\begin{array}{c}\bar{X} \\
\text { S.E. } \\
\text { N }\end{array}$ & $\begin{array}{c}32.0 \\
8.0 \\
4\end{array}$ & $\begin{array}{l}21.88 \\
3.42 \\
4\end{array}$ & $\begin{array}{l}2.000 \\
4^{.274}\end{array}$ & $4^{.063}$ & $\begin{array}{c}156.5 \\
3.8 \\
3\end{array}$ \\
\hline
\end{tabular}

${ }^{a}$ Caffeine specific concentration, i.e. mmol of caffeine required to raise the resting tension of a skeletal muscle fascicle by $1.0 \mathrm{gram}$ in absence of halothane.

"Caffeine specific concentration in presence of 1.0 volume per cent halothane.

Parathormone, calcitonin and vitamin $D$ play a regulating role in maintaining cell calcium concentrations within a narrow normal range $\left(10^{-6}\right.$ to $10^{-7}$ mol). The thyroid, sex-hormones, and glucocorticoid hormones also influence bone calcium metabolism. ${ }^{11-15}$ However, all patients studied exhibited normal serum calcium and phosphate levels. There was no other evidence of hyper-or hypo-parathyroidism in any individual. Thyroid function studies $\left(T_{3}, T_{4}, T S H, "\right.$ II uptake, $T_{3}$ uptake) were normal in all persons in the study. The levels of other hormones (sex, growth or adrenal) has been found to be normal in MHS patients. 
TABLE IV

t-TEST-AGE 16-60 YEARS

\begin{tabular}{|c|c|c|c|c|c|}
\hline t-Test ratios & Age & Caffeine & $\begin{array}{c}\text { Caffeine } \\
+ \\
\text { halothane }\end{array}$ & $\begin{array}{l}\text { Bone } \\
\text { calcium }\end{array}$ & $\begin{array}{c}\text { Present } \\
\text { measured } \\
\text { height }(\mathrm{cm})\end{array}$ \\
\hline $\begin{array}{l}\text { Rigid patient/rigid } \\
\text { relative" }^{*}\end{array}$ & 0.51 & 0.58 & 0.66 & 0.87 & 0.34 \\
\hline $\begin{array}{l}\text { Rigid patient/normal } \\
\text { relative }\end{array}$ & 0.26 & $3.34 \dagger$ & $3.66 \dagger$ & 2.13 & 0.03 \\
\hline $\begin{array}{l}\text { Rigid patient/non-rigid } \\
\text { patient }\end{array}$ & 0.11 & $4.29 \dagger$ & $2.83^{*}$ & 1.59 & 1.87 \\
\hline $\begin{array}{l}\text { Rigid relative/normal } \\
\text { relative }\end{array}$ & 1.13 & $4.35 \dagger$ & $4.72 \dagger$ & $2.04^{*}$ & 0.52 \\
\hline $\begin{array}{l}\text { Rigid relative/non-rigid } \\
\text { patient }\end{array}$ & 0.51 & $4.61 t$ & $2.82^{*}$ & $2.50^{*}$ & $2.35\left(^{*}\right)$ \\
\hline $\begin{array}{l}\text { Normal relative/non-rigid } \\
\text { patient }\end{array}$ & 0.07 & $2.25^{*}$ & 0.36 & $3.40 \uparrow$ & $2.02^{*}$ \\
\hline
\end{tabular}

$\bullet \mathrm{P}<0.05$

$+\mathrm{P}<0.01$

The $t$-values were obtained from comparisons based on analyses of variance. Their significance levels were assessed on the basis of the Tukey-Newman-Keuls $(A, B)$ sequential multiple comparison procedure.

(A) Newman, D. The distribution of the range in samples from a normal population expressed in terms of an independent estimate of the standard deviation Biometrika, 31, 20-30 (1939).

(B) Keuls, M. The use of the studentized range in connection with the analysis of variance. Euphyticam, 1 , 112-122 (1952)

TABLE V

Arithmetic Means for Male Patients

\begin{tabular}{|c|c|c|c|c|c|c|}
\hline $\begin{array}{l}\text { Patient } \\
\text { classification }\end{array}$ & & $\begin{array}{l}\text { Age } \\
\text { (yrs) }\end{array}$ & Caffeine $^{n}$ & $\begin{array}{c}\text { Caffeine } \\
+ \\
\text { halothane }\end{array}$ & $\begin{array}{l}\text { Bone } \\
\text { calcium } \\
\text { index }\end{array}$ & $\begin{array}{c}\text { Present } \\
\text { maximum } \\
\text { height }(\mathrm{cm})\end{array}$ \\
\hline $\begin{array}{l}\text { Rigid MHS } \\
\text { patients }\end{array}$ & $\begin{array}{l}\overline{\bar{X}} \\
\text { S.E. } \\
\text { N }\end{array}$ & $\begin{array}{l}30.44 \\
8.30 \\
9\end{array}$ & $\begin{array}{l}9.36 \\
1.61 \\
9\end{array}$ & $9^{.075}$ & $9^{.029}$ & $\begin{array}{c}161.76 \\
6.81 \\
8\end{array}$ \\
\hline $\begin{array}{l}\text { Rigid MHS } \\
\text { relatives }\end{array}$ & S.E. & $\begin{array}{l}35.8 \\
3.1 \\
25\end{array}$ & $\begin{array}{l}9.41 \\
1.02 \\
25\end{array}$ & $25^{.849}$ & $25^{.033}$ & $\begin{array}{r}171.2 \\
2.0 \\
25\end{array}$ \\
\hline $\begin{array}{l}\text { Normal } \\
\text { relatives }\end{array}$ & $\begin{array}{r}\bar{X} \\
\text { S.E. } \\
\text { N }\end{array}$ & $\begin{array}{r}22.82 \\
3.81 \\
17\end{array}$ & $\begin{array}{l}17.82 \\
1.91 \\
17\end{array}$ & $\begin{array}{r}1.994 \\
17\end{array}$ & $\begin{array}{r}1.015 \\
17^{.029^{\prime \prime}}\end{array}$ & $\begin{array}{r}159.93 \\
4.35 \\
16\end{array}$ \\
\hline $\begin{array}{l}\text { Non-rigid } \\
\text { MHS patients }\end{array}$ & $\begin{array}{r}\overline{\mathbf{X}} \\
\text { S.E. } \\
\mathbf{N}\end{array}$ & $\begin{array}{l}8.67 \\
2.67 \\
3\end{array}$ & $\begin{array}{l}32.0 \\
0.58 \\
3\end{array}$ & $\begin{array}{l}3.12 \\
.592 \\
3^{.59}\end{array}$ & $\begin{array}{l}.723 \\
.029 \\
3\end{array}$ & $\begin{array}{c}123.50 \\
7.00 \\
2\end{array}$ \\
\hline
\end{tabular}

"Caffeine specific concentration, i.e., mmol of caffeine required to raise the resting tension of a skeletal muscle fascicle by $1.0 \mathrm{gram}$ in absence of halothane.

'Caffeine specific concentration in presence of $1.0 \mathrm{vol} \%$ halothane.

Pyrophosphate is an inhibitor of precipitation of calcium from solution in blood and urine and inhibits crystal growth of bone calcium phosphate. ${ }^{16.17}$ Solomons ${ }^{18}$ has reported that some MHS patients, particularly those with non-rigid MH susceptibility, have elevated plasma pyrophosphate levels. Thus it could be that the low bone calcium concentration observed in our non-rigid MHS patients is secondary to an elevation of body pyrophosphate. This supposition is, however, purely speculative.

Alternatively or additionally there may be a primary defect in the osteocytes, osteoblasts and/or osteoclasts similar to that existing in the 
TABLE VI

t-Tests-MALES

\begin{tabular}{llcccc}
\hline \hline & Age & Caffeine & $\begin{array}{c}\text { Caffeine } \\
+ \\
\text { halothane }\end{array}$ & $\begin{array}{c}\text { Bone } \\
\text { calcium }\end{array}$ & $\begin{array}{c}\text { Present } \\
\text { measured } \\
\text { height }\end{array}$ \\
\hline $\begin{array}{l}\text { Rigid patient/rigid } \\
\text { relative }\end{array}$ & 0.80 & 0.02 & 0.23 & $3.21 \dagger$ & 1.62 \\
$\begin{array}{l}\text { Rigid patient/normal } \\
\text { relative }\end{array}$ & 1.08 & $3.41 \dagger$ & $5.72 \dagger$ & $4.75 \dagger$ & 0.30 \\
$\begin{array}{l}\text { Rigid patient/non-rigid } \\
\text { patient }\end{array}$ & 1.90 & $5.65 \dagger$ & $6.84 \dagger$ & 0.86 & $3.38 \dagger$ \\
$\begin{array}{l}\text { Rigid relative/normal } \\
\text { relaive }\end{array}$ & 2.41 & $4.45 \dagger$ & $7.21 \dagger$ & $2.26^{*}$ & $2.46^{*}$ \\
$\begin{array}{l}\text { Rigid relative/non-rigid } \\
\text { patient }\end{array}$ & 2.59 & $6.15 \dagger$ & $7.36 \dagger$ & $2.98^{*}$ & $4.54 \dagger$ \\
$\begin{array}{l}\text { Normal relative/non-rigid } \\
\text { patient }\end{array}$ & 1.32 & $3.77 \dagger$ & $3.56 \dagger$ & $4.04 \dagger$ & $3.93 \dagger$ \\
\hline
\end{tabular}

$* \mathbf{P}<0.05$

$\dagger \mathrm{P}<0.01$

-The $t$-values were obtained from comparisons based on analyses of variance. Their significance levels were assessed on the basis of the Tukey-Newman-Keuls (A, B) sequential multiple comparison procedure.

(A) Newman, D. The distribution of the range in samples from a normal population expressed in terms of an independent estimate of the standard deviation. Biometrika, 31, 20-30 (1939).

(B) Keuls, $M$. The use of the studentized range in connection with the analysis of variance. Euphytica, 1 , 112-122 (1952).

TABLE VII

Artthmetic Means for Female Patients

\begin{tabular}{|c|c|c|c|c|c|c|}
\hline $\begin{array}{l}\text { Patient } \\
\text { classification }\end{array}$ & & $\begin{array}{l}\text { Age } \\
\text { (yrs) }\end{array}$ & Caffeine $^{a}$ & $\begin{array}{c}\text { Caffeine } \\
+ \\
\text { halothane }^{\text {s. }}\end{array}$ & $\begin{array}{l}\text { Bone } \\
\text { calcium } \\
\text { index }\end{array}$ & $\begin{array}{c}\text { Present } \\
\text { maximum } \\
\text { height }(\mathrm{cm})\end{array}$ \\
\hline $\begin{array}{l}\text { Rigid MHS } \\
\text { patients }\end{array}$ & $\begin{array}{r}\overline{\mathbf{X}} \\
\text { S.E. } \\
\mathbf{N}\end{array}$ & $\begin{array}{l}25.13 \\
6.55 \\
8\end{array}$ & $\begin{array}{l}9.29 \\
1.47 \\
8\end{array}$ & $\begin{array}{l}1.077 \\
8^{.283}\end{array}$ & $8^{.057}$ & $\begin{array}{c}147.65 \\
9.92 \\
8\end{array}$ \\
\hline $\begin{array}{l}\text { Rigid MHS } \\
\text { relatives }\end{array}$ & $\begin{array}{r}\overline{\mathbf{X}} \\
\text { S.E. } \\
\mathbf{N}\end{array}$ & $\begin{array}{r}29.4 \\
2.9 \\
30\end{array}$ & $\begin{array}{l}8.57 \\
0.79 \\
30\end{array}$ & $30 . .980$ & $\begin{array}{r}.908 \\
30.023\end{array}$ & $\begin{array}{c}153.3 \\
2.3 \\
29\end{array}$ \\
\hline $\begin{array}{l}\text { Normal } \\
\text { relatives }\end{array}$ & $\begin{array}{r}\overline{\mathbf{X}} \\
\text { S.E. } \\
\mathrm{N}\end{array}$ & $\begin{array}{l}22.75 \\
3.25 \\
16\end{array}$ & $\begin{array}{l}16.30 \\
1.77 \\
16\end{array}$ & $\begin{array}{r}1.906 \\
16^{.114}\end{array}$ & $16^{.035}$ & $\begin{array}{r}152.76 \\
4.75 \\
15\end{array}$ \\
\hline $\begin{array}{l}\text { Non-rigid } \\
\text { MHS patients }\end{array}$ & $\begin{array}{r}\overline{\mathbf{X}} \\
\text { S.E. } \\
\mathbf{N}\end{array}$ & $\begin{array}{l}32.00 \\
8.03 \\
4\end{array}$ & $\begin{array}{r}21.88 \\
3.42 \\
4\end{array}$ & $\begin{array}{l}2.00 \\
4\end{array}$ & $4^{.063}$ & $\begin{array}{r}156.53 \\
3.84 \\
3\end{array}$ \\
\hline
\end{tabular}

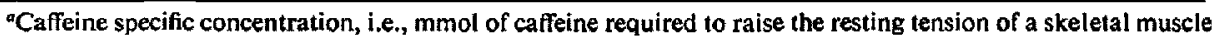
fascicle by $1.0 \mathrm{gram}$ in absence of halothane.

${ }^{\circ}$ Caffeine specific concentration in presence of 1.0 volume per cent halothane.

muscle cells of MHS patients. Thus defective osteocytic mitochondria might be incapable of taking up or binding normal amounts of calcium. On the other hand the outer membrane of the cells might be excessively permeable to calcium. Finally an excessive production of cyclic adenosine monophosphate (c-AMP) might induce a greater than normal release of calcium from otherwise normal mitchondria.

We are gratified that the greater deviation from normal has occurred in the non-rigid patients since this rare variant of $\mathrm{MH}$ has always been more difficult to diagnose than the rigid type of MH. For non-rigid patients this test, therefore, 
TABLE VIII

t-Tests-FEMALES

\begin{tabular}{|c|c|c|c|c|c|}
\hline t-Test ratios & Age & Caffeine & $\begin{array}{c}\text { Caffeine } \\
+ \\
\text { halothane }\end{array}$ & $\begin{array}{l}\text { Bone } \\
\text { calcium }\end{array}$ & $\begin{array}{l}\text { Present } \\
\text { measured } \\
\text { height }\end{array}$ \\
\hline $\begin{array}{l}\text { Rigid patient/rigid } \\
\text { relative }^{a}\end{array}$ & 0.69 & 0.34 & 0.30 & 1.26 & 1.58 \\
\hline $\begin{array}{l}\text { Rigid patient/normal } \\
\text { relative }\end{array}$ & 0.35 & $3.02 \dagger$ & $2.37^{*}$ & 0.31 & 0.69 \\
\hline $\begin{array}{l}\text { Rigid patient/non-rigid } \\
\text { patient }\end{array}$ & 0.72 & $3.84 t$ & 1.87 & $2.71^{*}$ & 0.78 \\
\hline $\begin{array}{l}\text { Rigid relative/normal } \\
\text { relative }\end{array}$ & 1.38 & $4.66 \dagger$ & $3.71 \uparrow$ & 1.19 & 1.03 \\
\hline $\begin{array}{l}\text { Rigid relative/non-rigid } \\
\text { patient }\end{array}$ & 0.31 & $4.67 \dagger$ & $2.38\left(^{*}\right)$ & $2.17^{*}$ & 0.17 \\
\hline $\begin{array}{l}\text { Normal relative/non-rigid } \\
\text { patient }\end{array}$ & 1.06 & 1.86 & 0.21 & $2.73^{*}$ & 0.35 \\
\hline \multicolumn{6}{|c|}{$\begin{array}{l}\text { * } P<0.05 \\
t P<0.01 \\
\text { The } t \text {-values were obtained from comparisons based on analyses of variance. Their significance levels were } \\
\text { assessed on the basis of the Tukey-Newman-Keuls }(A, B) \text { sequential multiple comparison procedure. } \\
\text { (A) Newman, D. The distribution of the range in samples from a normal population expressed in terms of an } \\
\text { independent estimate of the standard deviation. Biometrika, 31, 20-30 (1939). } \\
\text { (B) Keuls, } M \text {. The use of the studentized range in connection with the analysis of variance. Euphytica, } 1 \text {, } \\
112-122(1952) \text {. }\end{array}$} \\
\hline
\end{tabular}

provides a useful diagnostic complement to the caffeine contracture test. For the rigid MHS patients, however, the bone calcium index is so little different from the normal controls that it is not of value as a diagnostic test.

\section{SUMMARY}

Some non-rigid Malignant Hyperthermia Susceptible (MHS) patients have a greater than normal incidence of fractures. Radiologically their long bones are slightly thinner than normal. Excessive numbers of caries because of thin dental enamel may also be present.'

The Malignant Hyperthermic (MH) defect thus appears to involve cells of bone appendages as well as of muscle. We have measured the concentration of calcium in bone by neutron activation analysis and have found it to be reduced in both non-rigid and rigid malignant hyperthermia susceptible patients. The reductions were particularly marked for the non-rigid patients. Bone calcium concentrations were lower in males than in females and in those under 16 and over 60 years of age. This is additional evidence in favour of the hypothesis that malignant hyperthermia is a widespread defect affecting tissues and organs throughout the body.

\section{RÉSUMÉ}

Quelques uns des malades susceptibles à l"hyperthermie maligne présentent une incidence plus élevée de fractures que la normale. A l'examen radiologique, les os longs de ces malades sont plus minces que normalement. De plus, à cause de la minceur de l'émail dentaire, ils sonı quelquefois sujets à un nombre exagéré de caries dentaires.

Le défaut en cause dans l'hyperthermie maligne semble donc intéresser autant l'ossature que la musculature. Nous avons mesuré la concentration du calcium osseux par l'analyse par activation de neutrons et nous l'avons trouvée abaissée aussi bien chez les malades prédisposēs à la forme non rigide qu'à la forme rigide. Cette baisse était plus particulièrement marquée dans la forme non rigide que dans la forme rigide. La concentration du calcium osseux était plus basse chez les hommes que chez les femmes et chez ceux qui étaient moins âgés que 16 ans et plus âgés que 60 ans.

\section{REFERENCES}

I. BRITT, B.A. Unpublished data.

2. Harrison, J.E., McNeill, K.G., Meema, H.E. Oreopoulos, D., RAainovich, S., Fenton, S., \& 
WILson, D.R. In: Partial body calcium measurements on patients with renal failure. Metabolism 26: 3. 255-265 (1977).

3. Harrison, J.E.; Cumming, W.A., Fornasier, V., Fraser, D., Kooh, S.W., \& McNeill, K.G. In: Increased bone mineral content in young adults with familial hypophosphatemic vilamin D refractory rickets. Melabolism 25: 1, 33-39(1976)

4. MCNeill, K.G. \& Harkison, J.E. Measurement of the axial skeleton for diagnosis of osteoporosis by neutron activation analysis. J. Nucl. Med. 18: 1136-1137 (1977).

5. Harrison, J.E., Williams. W.C. Watts, J., \& MCNEILL, K.G. A bone calcium index based on partial-body calcium meusurements by in vivo acivation analysis. J. Nucl. Med. 16: 2, 116-122 (1975).

6. McNeill, K.G., Thomas, B.J., Sturtrioge, W.C., \& HARRISON, J.E. In vivo neutron activation analysis for calcium in man. J. Nucl. Med. 14: 502-506 (1973).

7. ANDERSON, J., OSBORN, S.B., \& TOMLINSON, R.W.S. Neutron-activation analysis in man $i n d i B O$. A new technique in medical investigation. Lancet II: 1201-1205 (1964).

8. Britt, B.A., Kaiow. W., \& Endrenyi, L. Malignant hyperthermia - pattern of inheritance in swine. Presented at the 2nd International Symposium on Malignant Hyperthermia, Denver, Colo., April 1-3, 1977.

9. BritT, B.A., MCCOMAS, A.J., ENDRENYI, L. \& KaLOW. $W$. Motor unit counting and the caffeine contracture test in malignant hyperthermia. Anesthesiology 47: 490-497 (1977).

10. Kalow, W., Britt, B.A., \& Peters, P. Rapid simplified techniques for measuring caffeine con- traction for patients with malignant hyperthermis. Presented at the 2nd International Symposium on Malignant Hyperthermia, Denver, Colo., April I-3, 1977.

11. Russell, R.G.G. Regulation of calcium metabolism. Ann. Clin Biochem. 13: 518-539 (1976).

12. Talmage, R.V., Cooper, C.W., \& Park, H.Z. Regulation of calcium transport in bone by parathyrcid hormone. Division of Biology and Medicine. Atomic Energy Commission, Washington, D.C.; Department of Pharmacology. School of Medicine, University of North Carolina, Chapel Hill, North Carolina; Department of Anatomy. School of Medicine, University of Utah, Salt Lake City, Utah. (103-141).

13. Rasmussen, H., Bordier, Kurokawa, K. Nagata, N., \& Ogata, E. Hormonal control of skeletal and mineral homeostasis. The American Journal of Medicine 56: 751-758 (1974).

14. Borle, A.B. Calcium metabolism at the cellular level. Federations Proceedings 32: 9, 1944-1950 (1973).

15. Nichols, G., JR. \& Rogers, P. Mechanisms fo: the transfer of calcium in to and out of the skeleton. Pediatrics 47: No. I, Part II, p. 211-228(1971).

16. Wadkins. C.L., Luben, R., Thomas, M., \& HuMPHREY, $R$. Physical binchemislry of calcification. Basic Science and Pathology. Clinical Orthopaedics and Related Research, Section 11, No. 99, p. 246-266 (Mar - Apr. 1974).

17. Russell, R.G.G. \& Fleisch, H. Inorganic pyrophosphate and pyrophasphatases in calcification and calcium homeostasis. Clinical Orthopaedics and Related Research 69: 101-117 (1970).

18. Solomons, C.C. Personal communication, Denver, Colorado (1974). 